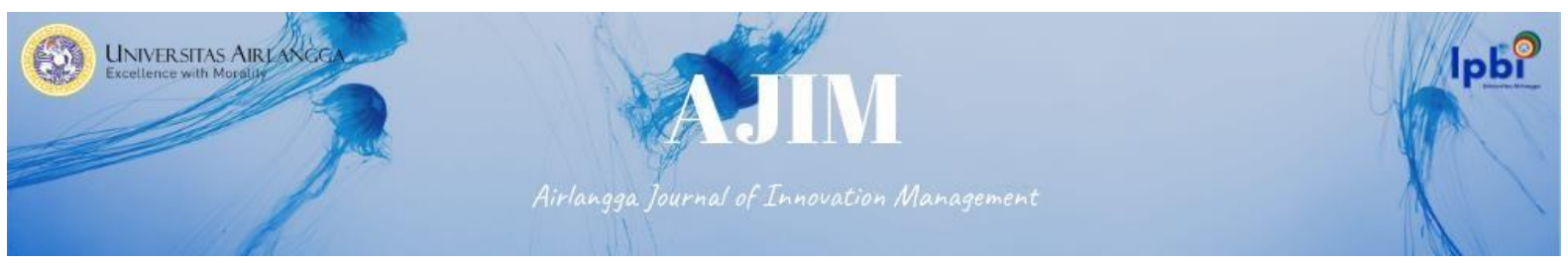

Vol. 2 No.1 Juni 2021

e-ISSN: 2722-5062

DOI : 10.20473/ajim.vvii.25759

\title{
BUSINESS PROCESS REENGINEERING IN BUSINESS PROCESS OF HAJJ AND UMRAH REGISTRATION SERVICES (CASE STUDY: MINISTRY OF RELIGION IN BALIKPAPAN CITY)
}

\author{
Ridha Auliya ${ }^{a}$, I Putu Deny A.S. Prabowo, S.Kom., M.Eng ${ }^{\text {b* }}$ \\ a,b Information Technology System. Institut Teknologi Kalimantan. Balikpapan. \\ *Corresponding e-mail : putudeny.asp@lecturer.itk.ac.id
}

\begin{abstract}
The Ministry of Religion Republic oIndonesia is a Ministry within Indonesian Government in charge of religious affairs. Ministry of Religion in Balikpapan can serve in fields of Education, Marriage, Waqf, Consultants on Household Issues, Mosque Construction, Hajj and others. Ministry of Religion in Field of Hajj and Umrah (PHU) Administrators as community organizers and facilitators who of course must behave professionally in serving, accompanying and assisting everything that is needed and prepared by prospective pilgrims before departure until returning to worship. Hajj and Umrah organizers as institutions within ministry of religion certainly need to fulfill demands of providing guidance. In this practical work, special task carried out at Ministry of Religion of City of Balikpapan is to carry out Business Process Reengineering in business process for Hajj registration services during COVID-19 pandemic, so that business process becomes more effective and efficient. Preparation of a business process reengineering by providing additional activities and reducing activities. The addition of this activity for prospective pilgrims is proposed to first check haj registration information on kemenag.go.id website or asramahajibalikpapan.co.id. An information on website is complete for community needs. So with prospective pilgrims who can check Hajj registration information online, it can eliminate misunderstandings and quality of service provided by Ministry of Religion is already very good.
\end{abstract}

Keywords : Business Process Reengineering, Service Quality, Hajj and Umrah Organizers

\section{Introduction.}

An organization or agency generally has a goal in order to survive and always improve its performance and productivity. To achieve this goal, an organization or agency needs a good business process. A business process consists of a series of activities carried out in coordination within organizational environment and technical environment. This activity aims to realize business goals (Weske, 2019).

According to Law of the Republic of Indonesia Number 8 Year (2019) regarding implementation of Hajj and Umrah emphasizes that Implementation of Hajj is a national task because number of Indonesian pilgrims is very large, involves various agencies and institutions, both domestic and foreign, and is related to various aspects including guidance, transportation, health, accommodation, and 


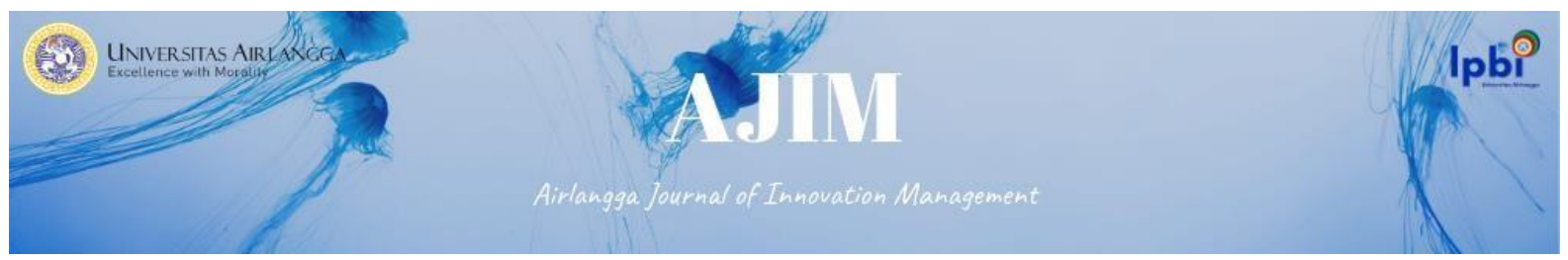

security As a form of public service, organizing Hajj requires transparency, openness and accountability. Service is provision of basic rights the community in accordance with their needs and interests which are regulated by regulations.

In this case what needs to be handled and receive special attention is Hajj and Umrah services given that more people are registering for pilgrimage. Even though in situation of Corona Virus Disease2019 (COVID-19) Pandemic in Balikpapan it is minimizing services, but it is also necessary quality of Hajj and Umrah Pilgrimage in a safe, comfortable, orderly manner and in accordance with provisions of Shari'a. This requires representative and continuous action, given that more prospective pilgrims are coming to ask for information about Hajj. Thus, performance of Hajj services needs to be considered so that services provided can run effectively and efficiently according to Kebijakan Walikota (2021) about "Pemberlakuan Pembatasan Kegiatan Masyarakat (PPKM) for Pengendalian Penyebaran Corona Virus Disease (COVID-19)" in Balikpapan and Instruction of Minister of Religion Republic of Indonesia Number 1 (2021).

In addition, activities of Hajj and Umrah organizers at Ministry of Religion of the City of Balikpapan also often experience misunderstanding conditions in communication between bank and prospective pilgrims, where bank provides information directly to Ministry of Religion to get a Portion Number. This causes prospective pilgrims who think, after making an initial deposit and then coming to Ministry of Religion, they have already obtained portion number for pilgrimage departure of prospective pilgrims. But in fact, prospective hajj pilgrims must register first and collect documents needed by Ministry of Religion, especially in Field of Haj and Umrah Organizers (PHU). So, it seems less efficient in terms of time and makes it difficult for prospective pilgrims who have to complete requirements needed for Hajj registration.

Based on these problems, the purpose of this analysis is to carry out Business Process Reengineering in business process for Hajj registration services during the COVID-19 pandemic, so that business process becomes more effective and efficient. Thus, there is a need for an analysis of hajj registration service business process with Business Process Reengineering which aims to evaluate service system and business process for hajj registration as well as procedures that have been implemented in Haj and Umrah Organizing Sector at Ministry of Religion of Balikpapan City.

\section{Literature Review Business Process}

Business process is a collection of work that is interrelated to solve a particular problem. A business process can be broken down into several sub-processes, each of which has its own attributes but also contributes to achieving its goals and sub-processes. Business process analysis generally involves mapping processes and sub-processes within them down to activity or activity level (IPQI, 2017). Business processes have several characteristics, among others (Sparx Systems, 2004):

1. Have a Purpose

2. Having a specific and specific input.

3. Having a certain and specific output.

4. Using resources.

5. Having a number of activities carried out in several sequences.

6. Can affect more than one organizational unit.

7. Creating a value for customers. customers can be internal or external 


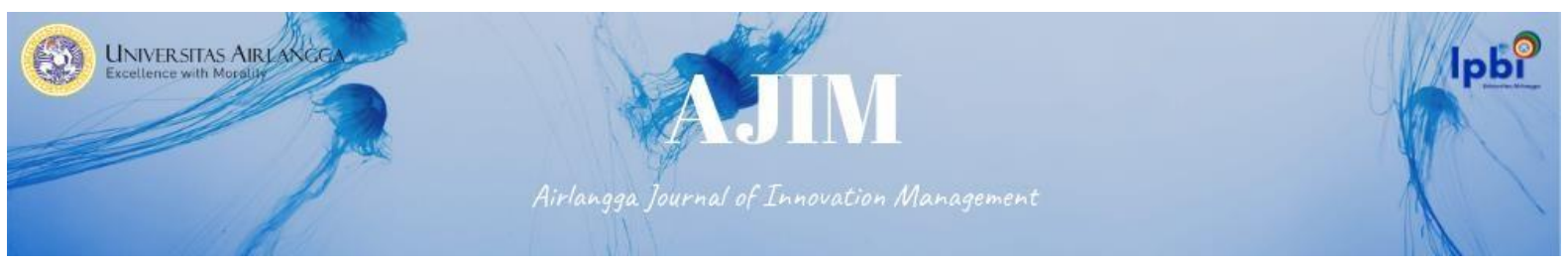

\section{Business Process Reengineering}

According to Hammer and Champy (1993), say that "Business Process Reengineering (BPR) is a fundamental rethinking and radical re-design of a business process to achieve dramatic improvements. By measuring current performance through elements of cost, quality, service and speed". Davenport and Short (1990), said that "Prioritizing 'process' in business process reengineering, by describing stages that must be passed".

Definition Business Process Reengineering (BPR) emphasizes redesign of a business process that challenges ongoing practices and aims to result in significant improvements or performance improvements in business process. Steps in reengineering that are commonly used are (Wisayani, 2014):

- Understand process that is taking place

- Identifying weak points in existing processes

- Investigate redesign alternatives

- Looking for opportunities to use Information Technology

- Model new, efficient processes

\section{Hajj Registration Procedures}

Procedures can be understood as steps and methods that must be taken to achieve a goal. Meanwhile, hajj registration is a series of activities carried out by government continuously and regularly, which includes recording identity, data collection and processing, bookkeeping and presentation and maintenance of data on pilgrims, including provision of portion numbers as proof of their rights and obligations. as a candidate for pilgrimage after fulfilling requirements and procedures set by government (NIDJAM, 2015).

In Regulation of the Minister of Religion (PMA) Republic of Indonesia Number 13 (2018) Regarding Implementation of Regular Hajj, Chapter II Terms and Procedures for Hajj Registration Article 7, that Hajj registration is carried out through following procedures:

- Pilgrimage Candidates make a transfer to Hajj Financial Management Agency (BPKH) account in amount of Rp25,000,000.00 Cost of organizing Hajj (BPIH) initial deposit;

- Banks Receiving Deposits for Hajj Organizing Fees (BPS BPIH) issues proof of Cost of organizing Hajj (BPIH) transfer that is printed through the application;

- Banks Receiving Deposits for Hajj Organizing Fees (BPS BPIH) issues 5 (five) pieces of proof of Cost of organizing Hajj (BPIH) initial deposit with details:

1. First sheet with a stamp duty for prospective Hajj pilgrims;

2. Second sheet for Banks Receiving Deposits for Hajj Organizing Fees (BPS BPIH);

3. Third sheet for Office of Ministry of Religion;

4. Fourth sheet for Regional Office;

5. Fifth sheet for Directorate General of Haj and Umrah;

6. Sixth sheet for Hajj Financial Management Agency (BPKH);

- Proof of Cost of organizing Hajj (BPIH) initial deposit as referred to in letter c, must include a Validation Number, signed, and affixed with a Banks Receiving Deposits for Hajj Organizing Fees (BPS BPIH) stamp, and each photo is $3 \times 4 \mathrm{~cm}$ (three by four centimeters);

- Banks Receiving Deposits for Hajj Organizing Fees (BPS BPIH) is obliged to submit sheet, fourth, and fifth sheet of proof of Cost of organizing Hajj (BPIH) initial deposit to Ministry of Religion Office no later than 5 (five) working days after the Cost of organizing Hajj (BPIH) initial deposit payment; 


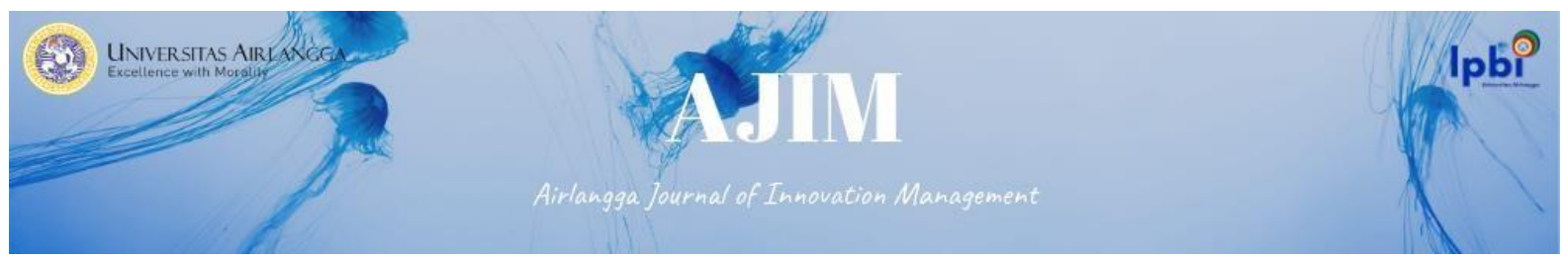

- Prospective Hajj pilgrims are required to submit registration requirements as referred to in Article 4 paragraph (1) and a copy of original Cost of organizing Hajj (BPIH) transfer proof printed from application as well as proof of Cost of organizing Hajj (BPIH) initial deposit to Ministry of Religion office officials to verify its completeness no later than 5 (five) working days. after Cost of organizing Hajj (BPIH) initial deposit payment;

- Prospective Hajj pilgrims fill out Hajj Registration Form in form of a Hajj registration letter and submit it to Ministry of Religion's office officials to be registered with Integrated Hajj Information and Computerization System and get a Portion Number;

- Prospective Hajj pilgrims receive proof of Hajj registration that has been signed and affixed with an official stamp by Office of the Ministry of Religion.

\section{Quality of Public Services}

Every public service must meet public expectations and this is what is meant by quality public service. Quality public services try to reduce gap (distance) between expectations and reality. Basically, good service quality is not based on service provider's perceptual point of view, but is based on customer's point of view / perception. Service quality is keeping service promises so that those served will feel satisfied and benefited. Improving service quality is everyone's job (Yusni, 2015).

According to Zeithaml (1990), develop Service Quality instruments to measure quality of service received by customers based on service quality models. Service Quality aims to measure quality dimensions developed with "RATER" criteria, which are as follows (Zeithaml, 1990) :

a. Reliability, includes knowledge to provide promised services reliably and accurately.

b. Assurance, includes knowledge and courtesy of employees in serving customers and their ability to maintain customer trust.

c. Tangibles, including the appearance of physical facilities, equipment, labor and communication tools.

d. Empathy, includes caring, individual attention provided by company to customers.

e. Responsiveness, includes willingness to help customers and provide services immediately.

\section{Method}

Methodology applied in completing this analysis is Business Process Reengineering at Ministry of Religion of Balikpapan in Field of Hajj and Umrah Organizers, which consists of 7 steps, namely as shown in Figure 1. Following:

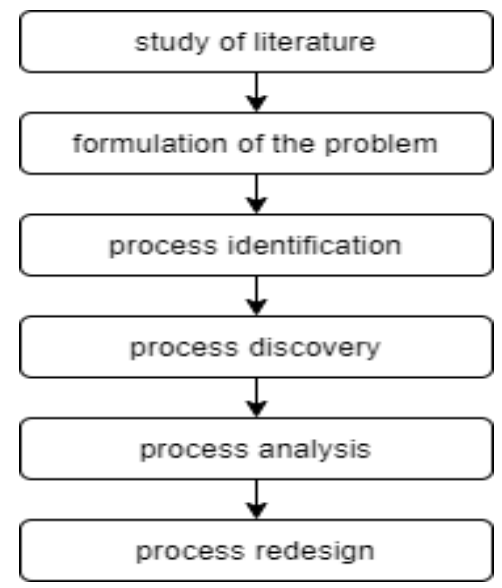

Figure 1 Research Methodology 


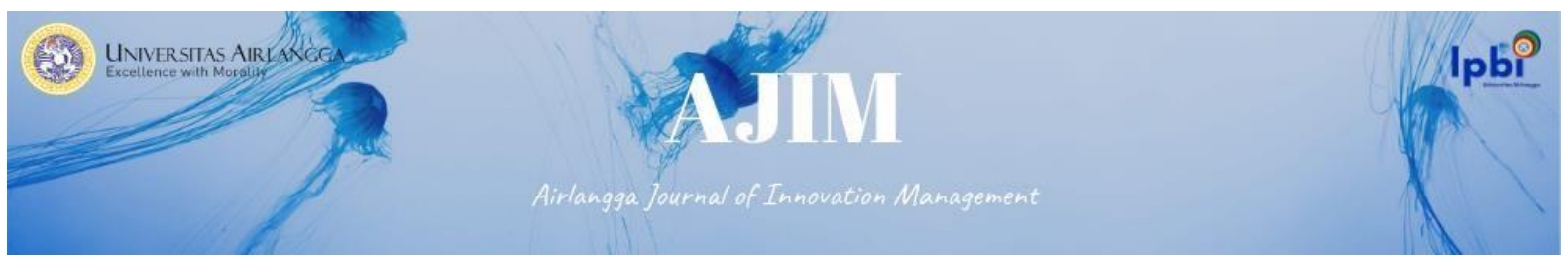

Methodology for completing analysis in Field of Hajj and Umrah Pilgrimage of Balikpapan, namely:

1. Literature Study

At this stage, researcher look for references, research journals and books relevant to discussion of practical work reports to support researcher knowledge of basic theories that will help in process of writing practical work reports.

2. Problem Formulation

At this stage, researcher seek and hold discussions with Section Head and staff regarding existing problems. Result of discussion can identify problems need to be analyzed with Business Process Reengineering in hajj registration service procedures.

3. Process Identification

After formulating problem, then collect all observation data, information and documents needed. This Process Identification, describes a process that has been realized.

4. Process Discovery

After identifying process, next step is process discovery stage. At process discovery stage, business process modeling is carried out using Business Process Model and Notation (BPMN) notation.

5. Process Analysis

Then at process analysis stage, a comparison of existing business processes with improved business process model is in terms of activity and time. In addition, from results of information data obtained in form of interviews about Hajj registration services, can be categorized according to service quality.

6. Process Redesign

At process redesign stage, process analysis was improved. If it does not cause problems from process analysis, then processes that have been compared do not need to be changed anymore because process has been running accordingly effectively and efficiently.

\section{Result And Discussion}

At this stage, a process identification is carried out in haj and umrah organizing sector at Ministry of Religion of Balikpapan. That there are several requirements for Hajj registration and business process flow in accordance with Standard Operating Procedure (SOP) at Ministry of Religion of Balikpapan. Following requirements must be completed when registering, namely.

1. Hajj Savings Book (Minimum Rp. 25,000,000 ,.)

2. Proof of Initial Deposit

3. Photocopy of Identity Card (KTP)

4. Photocopy of Family Card (KK)

5. Photocopy of Marriage Letter / Book

6. Photocopy of Birth Certificate

Also, hajj registration business process flow is modeled with Business Process Model and Notation (BPMN) notation in the image below. 

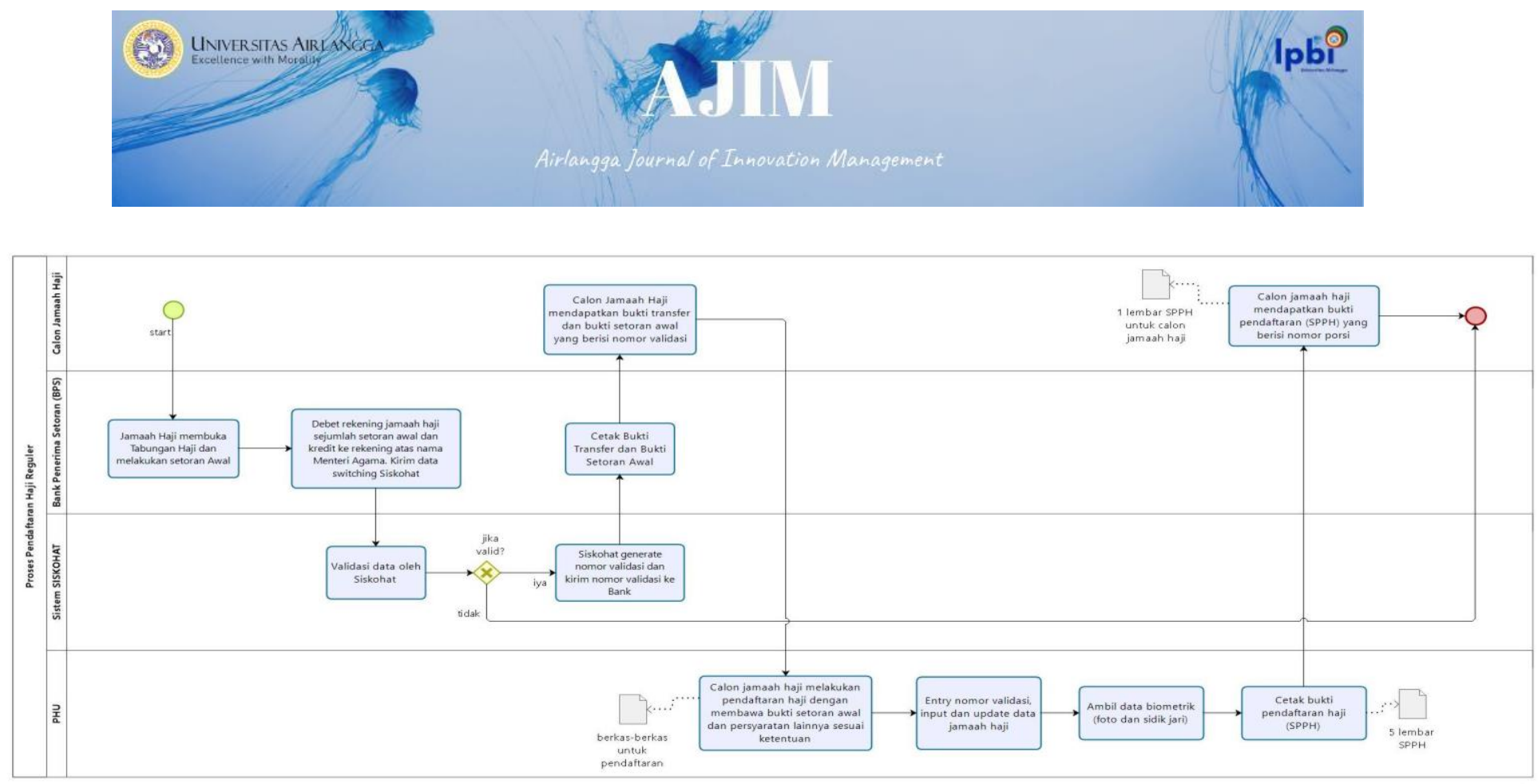

Figure 1 Process Identification Hajj Registration

Source: (Undang-Undang Republik Indonesia Nomor 8 , 2019)

In Figure 2 it can be explained that prospective pilgrims must open Hajj savings and make an initial deposit at a Deposit Recipient Bank (BPS). Then, debit pilgrims' account which is initial deposit and credit to account in name of Minister of Religion. From bank, it directly sends data to Integrated Hajj Computerized and Information System (SISKOHAT) switching system. After that, Siskohat will validate data. If valid, Siskohat generates a validation number to bank and prints proof of transfer and initial deposit. If data validation fails, data will be rejected the Siskohat system. Failure to validate data is usually due to data that does not match age requirements that must be over 12 years of age and have already made pilgrimage but not 10 years have passed after previous departure. Then, prospective pilgrims will get a transfer ticket and proof of initial deposit containing a validation number. This validation number will be used by pilgrims to register for Hajj by bringing proof of initial deposit and other requirements according to provisions. Then, validation number will be entered, input and update data of pilgrims, and take biometric data (photos and fingerprints). After being inputted, print proof of Hajj registration (SPPH), then, prospective pilgrims will get proof of Hajj registration (SPPH) which contains a portion number.

Related to Hajj registration services in Haj and Umrah Organizing Sector at Ministry of Religion of Balikpapan, it will be focused on quality of service provided by Umrah Hajj Organizer (PHU) employees to prospective pilgrims. This analysis will be associated with the theory that examines the quality of service in theory Zeithaml (1990),

From explanation above regarding quality of service, it can be described some of which are focus of research on the quality of Hajj registration services, namely in the following table. 


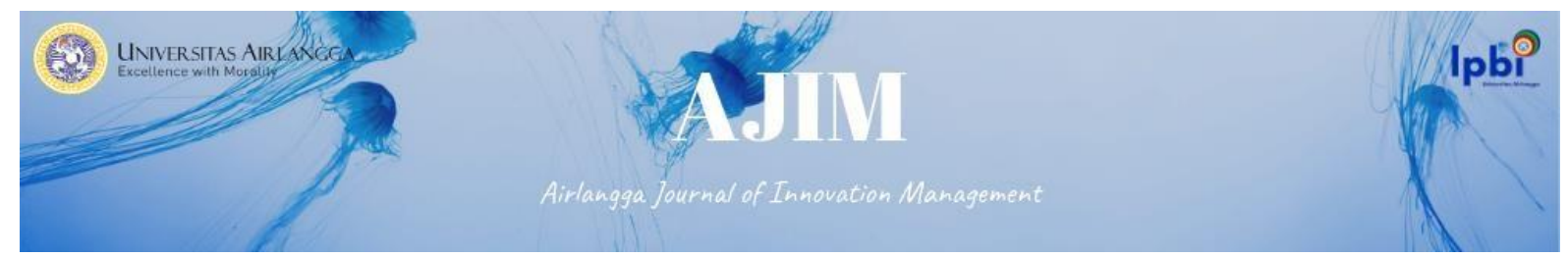

Tabel 1

Focus of Service Quality Research (Zeithaml, 1990)

\begin{tabular}{|c|c|c|}
\hline Variabel & \begin{tabular}{|l|} 
Service \\
Performance \\
Dimensions
\end{tabular} & Research Direction \\
\hline \multirow{5}{*}{$\begin{array}{l}\text { Service } \\
\text { Quality }\end{array}$} & Reliability & $\begin{array}{l}\text { a. Can solve the problems faced. } \\
\text { b. Providing services in a professional manner. } \\
\text { c. The ability of employees to serve adequately. }\end{array}$ \\
\hline & Assurance & $\begin{array}{l}\text { a. Having employees who can instill trust in the community. } \\
\text { b. Have sufficient employee skills so as not to cause concern }\end{array}$ \\
\hline & Tangible & $\begin{array}{l}\text { a. Equipment to provide adequate Hajj registration services. } \\
\text { b. Providing a complete and comfortable registration room. } \\
\text { c. Have employees dressed neatly and in uniform. }\end{array}$ \\
\hline & Empathy & $\begin{array}{l}\text { a. Be polite and friendly. } \\
\text { b. Give attention to the community. } \\
\text { c. Provide flexible service hours }\end{array}$ \\
\hline & Responsiveness & $\begin{array}{l}\text { a. Have employees who are ready to help the problems of } \\
\text { prospective pilgrims who register. } \\
\text { b. Have high alertness }\end{array}$ \\
\hline
\end{tabular}

After doing Process Identification, te next step is process discovery. At process discovery stage, business process modeling is carried out or current (existing) business processes using Business Process Model and Notation (BPMN) notation as basic basis for compiling Business Process Reengineering. To find out and understand problems that are object of this analysis, starting with modeling using Business Process Model and Notation (BPMN) of problems with pilgrim registration procedure and analyzing current business processes (existing) during COVID-19 pandemic based on results of observations that have been obtained in Hajj and Umrah Organizing Division at Ministry of Religion of Balikpapan.

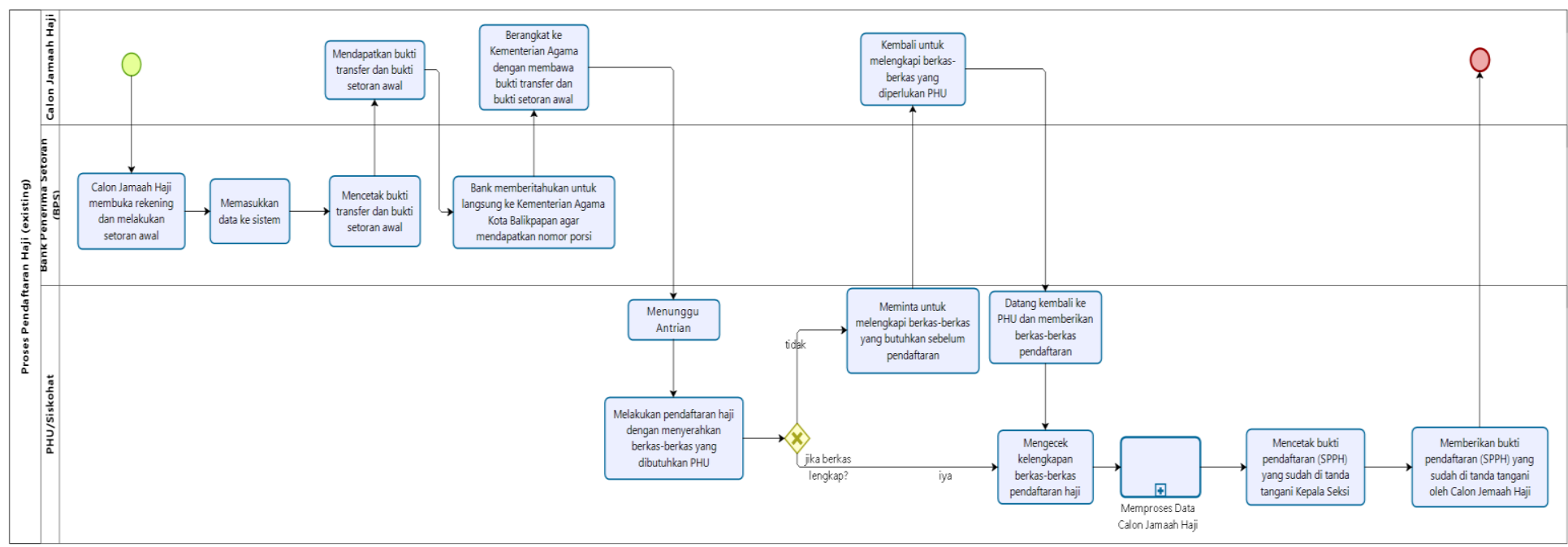

Figure 2. Hajj Registration Business Process

Source: (Existing data in field) 


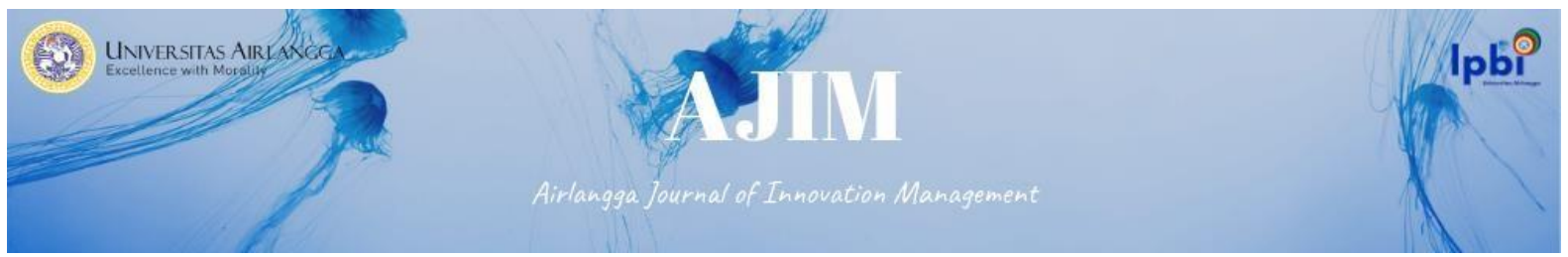

In Figure 3, it can be explained that prospective pilgrims must open an account and make an initial deposit of IDR 25,000,000. Then, Deposit Recipient Bank (BPS) will enter the data of prospective pilgrims into the SISKOHAT System (online). After that, BPS will print proof of transfer and proof of initial deposit. Then, proof of transfer and proof of initial deposit are given to prospective pilgrims and notify them to go directly to Ministry of Religion of Balikpapan to get a Portion Number. After that, prospective pilgrims go to the Ministry of Religion of Balikpapan with proof of transfer and proof of initial deposit. Prospective pilgrims can wait in line, after which they can register for hajj if they are invited by PHU officers or employees. If hajj registration files are complete, employee will double-check completeness of files and will immediately process them until they get a Hajj Registration Certificate (SPPH) with a portion number (hajj departure number) printed on it. However, if hajj registration documents are incomplete, then prospective pilgrims are asked to return to complete documents needed by Hajj and Umrah Organizers and then come back again to process complete files. This makes prospective pilgrims confused because they think they have received a portion number after making an initial deposit at a Deposit Recipient Bank (BPS). But in fact, prospective pilgrims must complete documents needed by Hajj and Umrah Organizers for completing Hajj registration data at SISKOHAT.

In Process Analysis stage, comparing existing business processes with improved business process models in terms of activity and time. The following is a table of activity stages along with the time of the existing Hajj registration process during the pandemic, namely.

Tabel 2.

\section{Business Process of Hajj Registration (Existing)}

\begin{tabular}{|c|c|c|c|}
\hline No. & Object of Observation & $\begin{array}{l}\text { Time } \\
\text { (WITA) }\end{array}$ & Information \\
\hline \multicolumn{4}{|c|}{ Activities 1} \\
\hline 1. & $\begin{array}{l}\text { Prospective pilgrims depart } \\
\text { from home to the bank. }\end{array}$ & 09.00 & \multirow{3}{*}{$\begin{array}{l}\text { Prospective hajj pilgrims open an account at a bank that } \\
\text { receives a deposit for Hajj Organizer Fees (BPS BPIH) } \\
\text { in accordance with Regulation of Minister of Religion } \\
\text { (2018) BPS BPIH carries out the process of recording } \\
\text { and issuing an account book that will be given by } \\
\text { prospective pilgrims. This account book is a requirement } \\
\text { for registering for hajj in order to get a portion number at } \\
\text { the Ministry of Religion Office. }\end{array}$} \\
\hline 2. & $\begin{array}{l}\text { Prospective pilgrims open an } \\
\text { account and make an initial } \\
\text { deposit. }\end{array}$ & 09.20 & \\
\hline 3. & $\begin{array}{l}\text { Prospective pilgrims receive } \\
\text { proof of transfer and proof of } \\
\text { initial deposit. }\end{array}$ & 09.30 & \\
\hline \multicolumn{4}{|c|}{ Activities 2} \\
\hline 4. & $\begin{array}{l}\text { Prospective pilgrims depart } \\
\text { from Bank to the Ministry of } \\
\text { Religion. }\end{array}$ & 10.00 & \multirow{4}{*}{$\begin{array}{l}\text { Prospective pilgrims submit proof of transfer and proof } \\
\text { of initial deposit. BPS BPIH issues five pieces of proof } \\
\text { of BPIH initial deposit, namely: } \\
\text { a. first sheet is stamped for prospective pilgrims } \\
\text { b. second sheet for BPS BPIH } \\
\text { c. third sheet for City Ministry of Religion Office. } \\
\text { d. fourth sheet for Provincial Regional Office. } \\
\text { e. fifth sheet for Directorate General of Haj and Umrah }\end{array}$} \\
\hline 5. & $\begin{array}{l}\text { Prospective pilgrims queue } \\
\text { and wait their turn. }\end{array}$ & 10.06 & \\
\hline 6. & $\begin{array}{l}\text { Prospective pilgrims submit } \\
\text { proof of transfer and proof of } \\
\text { initial deposit as requirement } \\
\text { for Hajj registration to obtain } \\
\text { portion number. }\end{array}$ & 10.10 & \\
\hline 7. & $\begin{array}{l}\text { If it is incomplete, employee } \\
\text { will provide an explanation } \\
\text { and direction regarding }\end{array}$ & 10.20 & \\
\hline
\end{tabular}




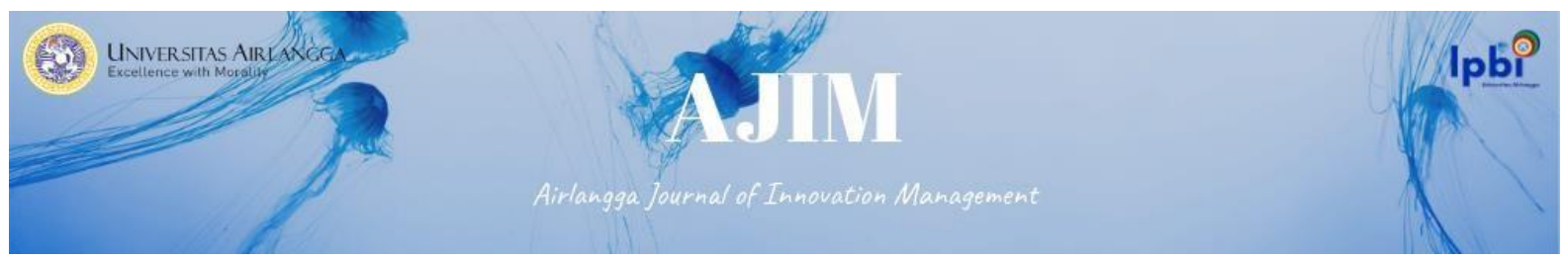

\begin{tabular}{|c|c|c|c|}
\hline & $\begin{array}{l}\text { documents that must be } \\
\text { completed }\end{array}$ & & \\
\hline \multicolumn{4}{|c|}{ Activities 3} \\
\hline 8. & $\begin{array}{l}\text { Prospective pilgrims return } \\
\text { home to complete required } \\
\text { files and make photocopies of } \\
\text { some of the files. }\end{array}$ & 10.40 & \multirow{2}{*}{$\begin{array}{l}\text { Prospective pilgrims must bring several requirements for } \\
\text { Hajj registration at the Ministry of Religion of the City } \\
\text { of Balikpapan. The required files such as: } \\
\text { 1. Hajj Savings Book (Minimum Rp. } 25,000,000, . \text { ) } \\
\text { 2. Proof of Initial Deposit } \\
\text { 3. Photocopy of Identity Card (KTP) } \\
\text { 4. Photocopy of Family Card (KK) } \\
\text { 5. Photocopy of Marriage Letter / Book } \\
\text { 6. Photocopy of Birth Certificate }\end{array}$} \\
\hline 9. & $\begin{array}{l}\text { Come back to Ministry of } \\
\text { Religion after files are } \\
\text { complete. }\end{array}$ & 11.00 & \\
\hline \multicolumn{4}{|c|}{ Activities 4} \\
\hline 10. & $\begin{array}{l}\text { The employee } \begin{array}{l}\text { will check } \\
\text { completeness }\end{array} \text { of hajj } \\
\text { registration files. }\end{array}$ & 11.05 & \multirow{3}{*}{$\begin{array}{l}\text { PHU employees will double-check completeness of files } \\
\text { and provide Hajj registration forms to prospective } \\
\text { pilgrims. After file for prospective pilgrims is complete, } \\
\text { it will be processed and inputted into SISKOHAT. Then, } \\
\text { take a photo shoot and take fingerprints of prospective } \\
\text { pilgrims and save them into SISKOHAT database. }\end{array}$} \\
\hline 11. & $\begin{array}{l}\text { Prospective pilgrims fill out } \\
\text { Hajj registration form. }\end{array}$ & 11.10 & \\
\hline 12. & $\begin{array}{l}\text { Employees will enter and } \\
\text { process data on prospective } \\
\text { pilgrims to SISKOHAT. }\end{array}$ & 11.20 & \\
\hline \multicolumn{4}{|c|}{ Activities 5} \\
\hline 13. & $\begin{array}{l}\text { Print five pieces registration } \\
(\mathrm{SPPH}) \text { and signed by Head of } \\
\text { PHU Section. }\end{array}$ & 11.30 & \multirow{3}{*}{$\begin{array}{l}\text { The registration letter for going to hajj (SPPH) is printed } \\
\text { in five sheets and signed by the Head of the PHU Section. } \\
\text { After that, it is given to prospective pilgrims to sign and } \\
\text { be stamped. Of the five sheets of Hajj Going Registration } \\
\text { (SPPH), PHU employees provide one sheet with a special } \\
\text { portion number for prospective pilgrims to be able to } \\
\text { check the departure time on the website } \\
\text { https://haji.kemenag.go.id/ or the Smart Hajj application } \\
\text { on Playstore. }\end{array}$} \\
\hline 14 & $\begin{array}{l}\text { Employees provide proof of } \\
\text { registration (SPPH) to } \\
\text { prospective pilgrims to be } \\
\text { signed as many as five pieces. }\end{array}$ & 11.35 & \\
\hline 15. & $\begin{array}{l}\text { Employees submit proof of } \\
\text { registration (SPPH) portion } \\
\text { number of one sheet for } \\
\text { prospective pilgrims. }\end{array}$ & 11.40 & \\
\hline \multicolumn{4}{|c|}{ Activities 6} \\
\hline 16. & Back to Home. & 12.00 & \multirow[t]{2}{*}{-} \\
\hline 17. & $\begin{array}{l}\text { Waiting for payment } \\
\text { according to year of departure } \\
\text { and time of departure. }\end{array}$ & - & \\
\hline
\end{tabular}

Source: Research result (2021)

Misunderstanding that occurs, is only a problem that can still be corrected. However, this also needs to be considered in terms of time, which is very ineffective and efficient, considering that service hours during pandemic are only up to 12.00 WITA, and PHU employees are only 2-3 people on duty according to their schedule of work. Especially if there are many regular hajj registrants, passports, cancellations of hajj, and those who want to get Hajj information at Ministry of Religion. This also makes prospective pilgrims wait their turn to be served their needs and also avoids things that are not possible, such as central signal to access SISKOHAT being an error causing prospective pilgrims to return next day. and make it easier for prospective pilgrims without any 


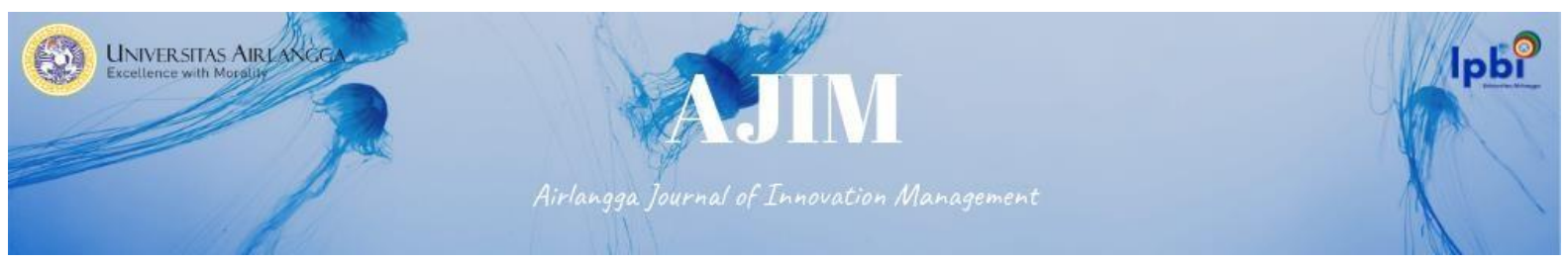

misunderstandings. Following stages in Business Process Reengineering business process for Hajj registration can be explained in table below.

Tabel 3.

Business Process Reengineering of Hajj Registration

\begin{tabular}{|c|c|c|c|}
\hline No & Object of Observation & $\begin{array}{l}\text { Time } \\
\text { (WITA) }\end{array}$ & Information \\
\hline \multicolumn{4}{|c|}{ Activities 1} \\
\hline 1. & $\begin{array}{l}\text { Prospective pilgrims check Hajj } \\
\text { registration procedure and } \\
\text { requirements on kemenag.go.id or } \\
\text { asramahajibalikpapan.co.id. }\end{array}$ & 08.00 & \multirow{4}{*}{$\begin{array}{l}\text { Before prospective pilgrims open an account for } \\
\text { Hajj, be sure to check some of requirements and } \\
\text { procedures for registering Hajj on kemenag.go.id } \\
\text { website or asramahajibalikpapan.co.id. After } \\
\text { understanding Hajj registration procedure, } \\
\text { prospective pilgrims can prepare required } \\
\text { documents. Prospective hajj pilgrims open an } \\
\text { account at a bank that receives a deposit for Hajj } \\
\text { Organizer Fees (BPS BPIH) in accordance with } \\
\text { Regulation of Minister of Religion (2018). BPS } \\
\text { BPIH carries out process of recording and issuing an } \\
\text { account book that will be given by prospective } \\
\text { pilgrims. This account book is a requirement for } \\
\text { registering for hajj in order to get a portion number } \\
\text { at Ministry of Religion Office. }\end{array}$} \\
\hline 2. & $\begin{array}{l}\text { Prospective pilgrims depart from } \\
\text { home to bank. }\end{array}$ & 09.00 & \\
\hline 3. & $\begin{array}{l}\text { Prospective pilgrims open an } \\
\text { account and make an initial deposit. }\end{array}$ & 09.20 & \\
\hline 4. & $\begin{array}{l}\text { Prospective pilgrims receive proof } \\
\text { of transfer and proof of initial } \\
\text { deposit. }\end{array}$ & 09.30 & \\
\hline \multicolumn{4}{|c|}{ Activities 2} \\
\hline 5. & $\begin{array}{l}\text { Prospective pilgrims depart from } \\
\text { Bank to Ministry of Religion. }\end{array}$ & 10.00 & \multirow{5}{*}{$\begin{array}{l}\text { Prospective pilgrims must bring several } \\
\text { requirements for Hajj registration at Ministry of } \\
\text { Religion of Balikpapan. such as: } \\
\text { 1. Hajj Savings Book (Minimum Rp. 25,000,000,.) } \\
\text { 2. Proof of Initial Deposit } \\
\text { 3. Photocopy of Identity Card (KTP) } \\
\text { 4. Photocopy of Family Card (KK) } \\
\text { 5. Photocopy of Marriage Letter / Book } \\
\text { 6. Photocopy of Birth Certificate } \\
\text { PHU employees will check completeness of files } \\
\text { and provide Hajj registration forms to prospective } \\
\text { pilgrims. After file for prospective pilgrims is } \\
\text { complete, it will be processed and inputted into } \\
\text { SISKOHAT. Then, take a photo shoot and take } \\
\text { fingerprints of prospective pilgrims and save them } \\
\text { into the SISKOHAT database. }\end{array}$} \\
\hline 6. & $\begin{array}{l}\text { Prospective pilgrims queue and wait } \\
\text { their turn. }\end{array}$ & 10.06 & \\
\hline 7. & $\begin{array}{l}\text { Prospective pilgrims submit proof } \\
\text { of transfer and proof of initial } \\
\text { deposit along with completeness of } \\
\text { documents for Hajj registration } \\
\text { requirements. }\end{array}$ & 10.07 & \\
\hline 8. & $\begin{array}{l}\text { Employees will check completeness } \\
\text { of hajj registration documents and } \\
\text { pilgrims will fill out hajj } \\
\text { registration form. }\end{array}$ & 10.12 & \\
\hline 10. & $\begin{array}{l}\text { Employees will enter data and } \\
\text { process data on prospective } \\
\text { pilgrims to SISKOHAT database. }\end{array}$ & 10.20 & \\
\hline \multicolumn{4}{|c|}{ Activities 3} \\
\hline 11. & $\begin{array}{l}\text { Print five pieces of proof of } \\
\text { registration (SPPH) and signed by } \\
\text { Head of the PHU Section. }\end{array}$ & 10.25 & \multirow{2}{*}{$\begin{array}{l}\text { The registration letter for going to hajj (SPPH) is } \\
\text { printed in five sheets and signed by Head of PHU } \\
\text { Section. After that, it is given to prospective } \\
\text { pilgrims to sign and be stamped. Of five sheets of } \\
\text { Hajj Going Registration (SPPH), PHU employees } \\
\text { provide one sheet with a special portion number for } \\
\text { prospective pilgrims to be able to check the }\end{array}$} \\
\hline 12. & $\begin{array}{l}\text { Employees provide proof of } \\
\text { registration (SPPH) to prospective } \\
\text { pilgrims to be signed as many as } \\
\text { five pieces. }\end{array}$ & 10.30 & \\
\hline
\end{tabular}




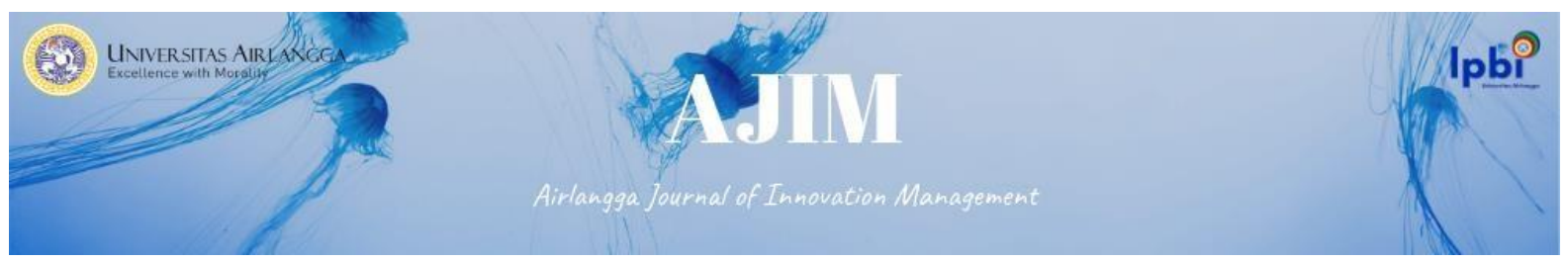

\begin{tabular}{|c|c|c|c|c|c|c|}
\hline 13. & $\begin{array}{l}\text { Employees submit proof of } \\
\text { registration }(\mathrm{SPPH}) \text { along with } \\
\text { portion number of one sheet for } \\
\text { prospective pilgrims. }\end{array}$ & 10.35 & $\begin{array}{l}\text { departure time } \\
\text { https://haji.kemenag.go.id/ } \\
\text { application on Playstore }\end{array}$ & $\begin{array}{l}\text { on } \\
\text { or }\end{array}$ & Smart & $\begin{array}{r}\text { website } \\
\text { Hajj }\end{array}$ \\
\hline \multicolumn{7}{|c|}{ Activities 4} \\
\hline 14. & Back to Home & 10.50 & \multirow[t]{2}{*}{-} & & & \\
\hline 15. & $\begin{array}{l}\text { Waiting for payment according to } \\
\text { year and time of departure. }\end{array}$ & - & & & & \\
\hline
\end{tabular}

Source: Research result (2021)

In addition, from results of information data obtained in form of interviews about Hajj registration services, it can be categorized according to service quality. The following is a table from results of observations obtained regarding Hajj registration services in the Haj and Umrah Organizing Sector at the Ministry of Religion of the City of Balikpapan.

Tabel 4. Service Quality in field of Hajj and Umrah organizers

\begin{tabular}{|c|c|c|c|}
\hline No. & $\begin{array}{c}\text { Service } \\
\text { Performance } \\
\text { Dimensions }\end{array}$ & Research Direction & Service Object \\
\hline 1. & Reliability & $\begin{array}{l}\text { a. Can solve problems faced. } \\
\text { b. Providing services in a } \\
\text { professional manner. } \\
\text { c. The ability of employees to } \\
\text { serve adequately. }\end{array}$ & $\begin{array}{l}\text { a. Punctuality in Hajj registration } \\
\text { services } \\
\text { b. reliability of employees in providing } \\
\text { professional registration services. } \\
\text { c. The ability of PHU employees is } \\
\text { sufficient and able to solve problems }\end{array}$ \\
\hline 2. & Assurance & $\begin{array}{l}\text { a. Having employees who can } \\
\text { instill trust in the community. } \\
\text { b. Have sufficient employee } \\
\text { skills so as not to cause } \\
\text { concern }\end{array}$ & $\begin{array}{l}\text { a. PHU employees instill trust and do } \\
\text { not cause concern to community. } \\
\text { b. Guarantee to provide services and } \\
\text { obtain a portion number for pilgrims } \\
\text { (SPPH). } \\
\text { c. Have security in service activities. }\end{array}$ \\
\hline 3. & Tangible & $\begin{array}{l}\text { a. Equipment to provide adequate } \\
\text { Hajj registration services. } \\
\text { b. Providing a complete and } \\
\text { comfortable registration room. } \\
\text { c. Have employees dressed neatly } \\
\text { and in uniform. }\end{array}$ & $\begin{array}{l}\text { a. Adequate registration support } \\
\text { facilities. } \\
\text { b. A special room for Hajj and Umrah } \\
\text { organizers. } \\
\text { c. Has a secure parking space. } \\
\text { d. The appearance of PHU employees is } \\
\text { neat and uniform. }\end{array}$ \\
\hline 4. & Empathy & $\begin{array}{l}\text { a. Be polite and friendly. } \\
\text { b. Give attention to community. } \\
\text { c. Provide flexible service hours }\end{array}$ & $\begin{array}{l}\text { a. Give attention to community by being } \\
\text { polite and friendly. } \\
\text { b. Provide flexible service hours } \\
\text { according Kebijakan Walikota (2021). }\end{array}$ \\
\hline 5 . & Responsiveness & $\begin{array}{l}\text { a. Have employees who are ready } \\
\text { to help problems of } \\
\text { prospective pilgrims who } \\
\text { register. } \\
\text { b. Have high alertness }\end{array}$ & $\begin{array}{l}\text { a. Have responsiveness of PHU } \\
\text { employees in serving and handling } \\
\text { Hajj registration issues. } \\
\text { b. PHU employee responsiveness in } \\
\text { answering questions. } \\
\text { c. Readiness and availability of officers } \\
\text { in assisting prospective pilgrims. }\end{array}$ \\
\hline
\end{tabular}




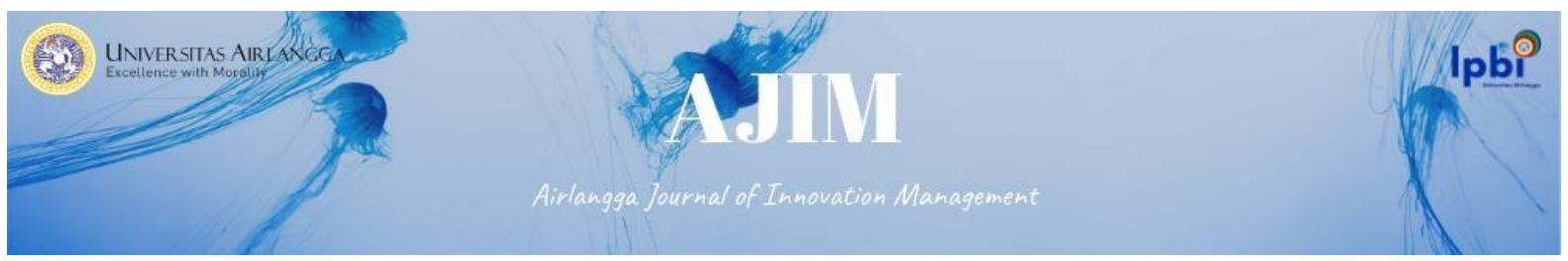

At process redesign stage, process analysis was improved. Addition of business processes has been carried out and there have been several deletions in process where there are no problems with misunderstanding of Deposit Recipient Bank. Here is a new design for Hajj registration business process.

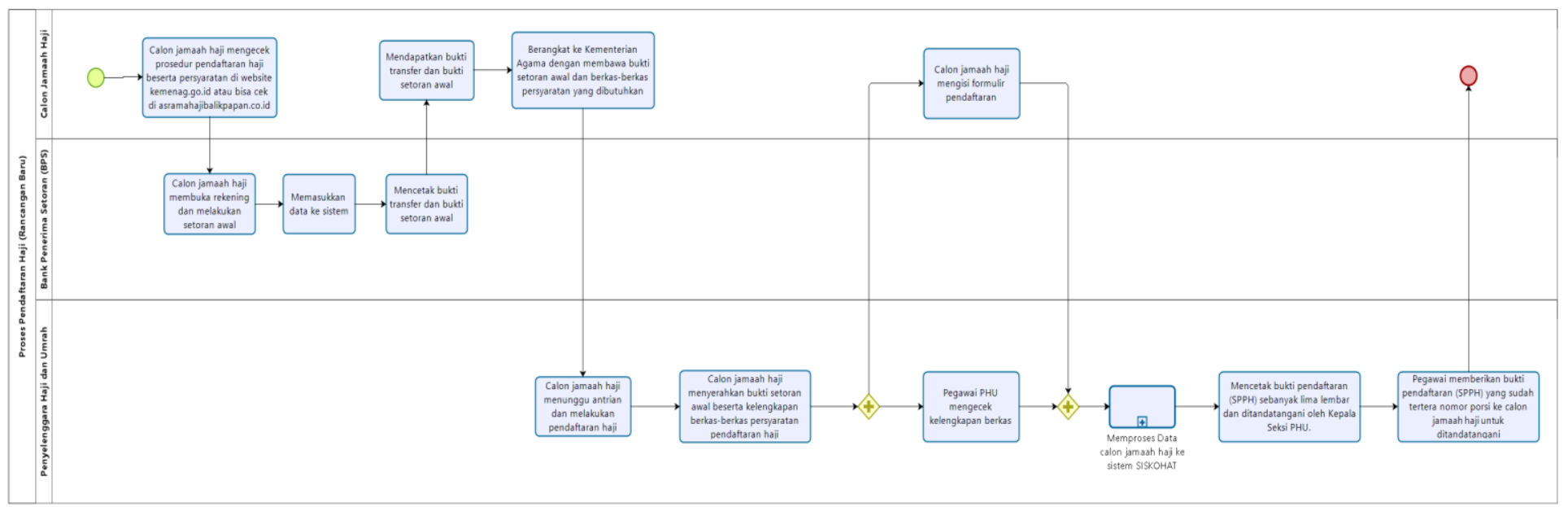

Figure 4. The Result Business Process Reengineering of Hajj Registration

Source: Research result (2021)

In Figure 4, it can be explained that prospective pilgrims should first know information on kemenag.go.id website to find out procedures and requirements for Hajj registration. This avoids prospective pilgrims who have to return home to complete required documents. So that by checking website or information about online Hajj registration, prospective pilgrims can collect required files. Then, prospective pilgrims will go to Deposit Recipient Bank (BPS) to open an account and make an initial deposit of IDR 25,000,000. After Deposit Recipient Bank (BPS) provides proof of transfer and proof of initial deposit, prospective pilgrims go directly to Ministry of Religion of Balikpapan in Haj and Umrah Organizing Sector by bringing other files. After that, wait in line and wait for Hajj registration service. When it is their turn, prospective pilgrims provide complete documents and fill out Hajj registration form and employees will check completeness of documents of prospective pilgrims. Then, PHU employees will process data to SISKOHAT system. Prospective pilgrims will be summoned in turn to take photos and fingerprints which will be attached to Hajj Registration Certificate (SPPH). SPPH that has been printed will be signed in advance by Head of PHU Section, and also signed by prospective pilgrims. Then, SPPH sheet is stamped and one sheet is given with portion number for prospective hajj pilgrims and four sheets for data at Ministry of Religion.

\section{Conclusion}

Based on analysis result carried out a special task of practical work at Ministry of Religion of Balikpapan, following conclusions were obtained.

1. Preparation of a Business Process with a Business Process Reengineering by providing additional activities and reducing activities. addition of this activity for prospective pilgrims is proposed to first check haj registration information on the kemenag.go.id website or asramahajibalikpapan.co.id. The information on website is complete for community needs. So with presence of prospective pilgrims who can check Hajj registration information online, it can 


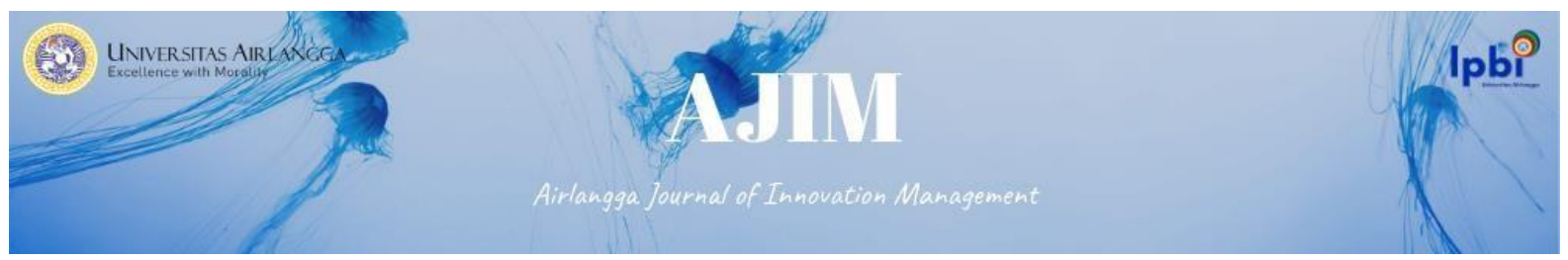

eliminate misunderstandings, especially since Hajj services are currently only limited to half a day in accordance with Mayor's Policy (2021).

2. Ministry of Religion of City of Balikpapan has implemented a very good Service Quality. The quality of service includes Reliability, Assurance, Tangibles, Empathy, and Responsiveness with the following conclusions:

a. Reliability, is the punctuality of registration services and reliability of PHU employees at Ministry of Religion of Balikpapan in serving the community for registering the pilgrimage.

b. Assurance, this is Office of the Ministry of Religion of Balikpapan has confidence in prospective pilgrims by providing a portion number as a guarantee and good and safe service in the haj registration process.

c. Tangibles, at Office of Ministry of Religion of Balikpapan as a support for quality of Hajj registration services by providing Hajj and Umrah Organizing Rooms (PHU), registration support facilities and information provided by office to prospective pilgrims quickly and accurately.

d. Empathy, a PHU employee at Ministry of Religion of Balikpapan tries to understand customers and pay attention to prospective pilgrims in registering for pilgrimage if they experience difficulties.

e. Responsiveness, PHU employees at Ministry of Religion of Balikpapan are able to respond to requests, complaints, questions from prospective pilgrims in serving and handling problems experienced by prospective pilgrims..

\section{Reference}

Aditya Susilo, dkk. (2020). Coronavirus Disease 2019: Review of Current Literatures. Jurnal Penyakit Dalam Indonesia Vol. 7, No. 1 , 45-67.

Davenport, T. H. (1990). Process Innovation: Reengineering Work through Information Technology. Boston: Harvard Business School Press.

Hammer, Michael and James Champy. (1993). Reenginering The Corporation. New York: Harper Collins.

Instruksi Menteri Agama Republik Indonesia. (2021). Peningkatan Disiplin Penerapan Protokol Kesehatan Dalam Pencegahan dan Pengendalian Corona Virus Disease 2019 Pada Kementerian Agama. 9 Februari 2021. Jakarta: Menteri Agama Republik Indonesia.

IPQI. (2017). Business Process Management. Jakarta: Proxsis.

Jeston, John and Johan Nelis. (2006). Business Process Management. Canada: Elsevier.

Kebijakan Walikota. (2021). Pemberlakuan Pembatasan Kegiatan Masyarakat (PPKM) Untuk Pengendalian Penyebaran Corona Virus Disease (COVID-19) di Kota Balikpapan. Balikpapan: Wali Kota Balikpapan.

Marlon Dumas, d. (2013). Fundamentals of Business Process Management. New York: Springer.

NIDJAM, A. (2015). THE EFFECTIVENESS OF HAJJ REGISTRATION PROCEDURE THROUGH BUSINESS PROCESS RE-ENGINEERING. Jurnal PENAMAS Volume 28, Nomor 3, Halaman 413 - 426.

Parwanto, M. (2020). Virus Corona (2019-nCoV) penyebab COVID-19. Jurnal Biomedika dan Kesehatan Vol. 3 No. 1, 1-2.

Peraturan Menteri Agama Republik Indonesia Nomor 13. (2018). Tentang Penyelenggaraan Ibadah Haji Reguler. Jakarta: Berita Negara Republik Indonesia Nomor 538.

Peraturan Presiden Republik Indonesia Nomor 83. (2015). Tentang Kementerian Agama. 15 Juli 2015. Jakarta: LEMBARAN NEGARA REPUBLIK INDONESIA NOMOR 168. 


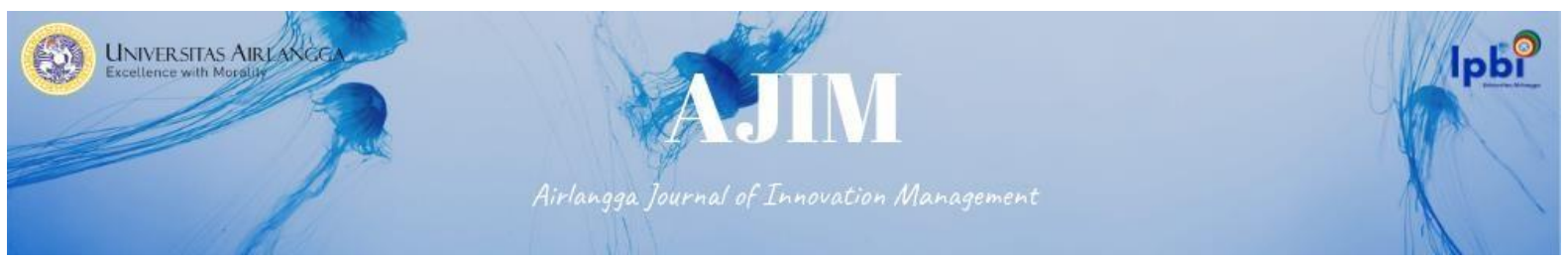

Ramdhani, M. A. (2015). PEMODELAN PROSES BISNIS SISTEM AKADEMIK MENGGUNAKAN PENDEKATAN BUSINESS PROCESS MODELLING NOTATION (BPMN) (STUDI KASUS INSTITUSI PERGURUAN TINGGI XYZ) . Jurnal Informasi Volume VII No.2, 83-93.

Sparx Systems. (2004). UML Tutorials: The Business Process Model. Australia: Sparx Systems.

Undang-Undang Republik Indonesia Nomor 25. (2009). Tentang Pelayanan Publik. Jakarta: Lembaran Negara Republik Indonesia Nomor 112.

Undang-Undang Republik Indonesia Nomor 8 . (2019). Tentang Penyelenggaraan Haji dan Umrah. Jakarta: LEMBARAN NEGARA REPUBLIK INDONESIA Nomor 75.

Weske, M. (2019). Business Process Management : Third Edition. Germany: Springer.

Wisayani, N. L. (2014). ANALISIS BUSINESS PROCESS REENGINEERING UNTUK MENGEVALUASI,MEREKAYASA ULANG, DAN MEMPERBAIKI MONITORING KONTRAK PADA PT PLN (PERSERO) DIST. JATIM AREA MALANG. Jurnal Administrasi Bisnis (JAB)| Vol. 8 No. 1, 1-10.

Yusni, M. A. (2015). STUDI TENTANG PELAYANAN HAJI DI KEMENTERIAN AGAMA KOTA SAMARINDA. eJournal Ilmu Pemerintahan, 3 (1) ISSN 2338 - 3651, ejournal.ip.fisipunmul.ac.id, 318-332.

Zeithaml. (1990). Delivery Quality Service: Balancing Customer Perceptions and Expectiations. New York: The Free Press. 